\title{
Association between Inflammation and Malnutrition as Risk Factors of Cardiovascular Disease
}

\author{
George A. Kaysen \\ Division of Nephrology, Departments of Medicine and Biochemistry, University of California, Davis, Calif., and \\ Research Service Department of Veterans Affairs Northern California Health Care System, Mather, Calif., USA
}

\section{Key Words}

High-density lipoprotein • Vascular endothelium • Sarcopenia

\begin{abstract}
Cardiovascular disease is the leading cause of death among dialysis patients. The relative risk of mortality increases as serum albumin concentration and body mass index decline. While these are generally associated with nutritional status, inflammation causes sarcopenia and decreased albumin concentration by reducing synthesis of proteins and increasing their catabolic rate. While inflammation can arise from atherosclerotic blood vessels, systemic inflammation from any source can alter the vascular endothelium and plasma protein composition in ways that promotes vascular injury. High-density lipoprotein synthesis is decreased and the high-density lipoprotein present is less capable of reducing inflammation. Activation of neutrophils favors lipoprotein oxidation. Surprisingly, while obesity is associated with cytokine production in patients without renal failure, as well as among dialysis patients, increased body mass index, whether reflecting muscle mass or adipose tissue, is associated with a decline in mortality rates.
\end{abstract}

Copyright @ 2006 S. Karger AG, Basel
(C) $2006 \mathrm{~S}$. Karger $\mathrm{AG}$, Basel

$0253-5068 / 06 / 0241-0051 \$ 23.50 / 0$

Fax +41613061234 E-Mail karger@karger.ch www.karger.com
The incidence of cardiovascular events and death from cardiovascular disease is massively increased in dialysis patients [1]. Hypoalbuminemia, thought to be primarily an indicator of malnutrition, was recognized as having a strong association with mortality in these patients [2]. Subsequently, it became recognized that serum albumin concentration was controlled at least in part by inflammation by its association with $\mathrm{C}$-reactive protein (CRP) [3] and proinflammatory cytokines [4]. Isolated protein calorie malnutrition does not lead to hypoalbuminemia except at preterminal levels of starvation [5].

Body composition is affected by both nutrition and inflammation [6]. While inadequate nutritional intake can result in a decrease in serum albumin [7] and muscle protein wasting [7, 8], inflammation can also affect these nutritional measures $[9,10]$. Indeed, malnutrition alone, except preterminally [5], has very little effect on plasma protein composition. It is the combination of both malnutrition and inflammation that effects the greatest change [11]. Inflammation, acting through nuclear factor$\mathrm{kB}$ stimulates ubiquitin-mediated proteolysis of muscle leading to muscle protein catabolism [12] and impairs repair mechanisms [13] leading to loss of muscle mass [14]. Thus, inflammation plays an important role in mediating loss of muscle mass $[12,15]$. This in turn leads to reduction in creatinine generation [16]. The decline in serum creatinine, reflecting a decline in creatinine generation, is associated with both nutritional factors and inflammation [6]. 
Inflammation causes a decline in serum albumin concentration by a combination of mechanisms. Albumin synthesis is decreased [17]. One of the adaptive responses that defends albumin mass when protein is restricted is that of a reduction in the fractional catabolic rate of albumin. Plasma protein composition including serum albumin levels, and to a lesser extent muscle mass, is maintained at nearly normal levels in subjects with anorexia nervosa, in part by a reduction in resting energy expenditure, total net protein catabolism and also a decrease in the fractional catabolic rate [18]. In contrast, patients with wasting and infection as a consequence of the human immunodeficiency virus have an increased resting energy expenditure that is even more marked in the presence of diagnosed infection [19] as well as hypoalbuminemia. Alterations in the albumin fractional catabolic rate play an important role in sustaining albumin concentration during protein restriction [20,21]. Inflammation removes this adaptive mechanism for responding to periods of decreased nutritional intake [10]. The level of inflammation that results in changes in nutritional markers, muscle wasting and hypoalbuminemia is great.

The potential sources of cytokines are several. Atherosclerosis is an inflammatory process [22]. Atherosclerosis nutritionally induced in a porcine model can be demonstrated to recruit CRP to the site of atherosclerosis [23]. CRP itself may play a role in promoting or propagating vascular injury through complement recruitment [24]. At the same time, pyrogenic infections are associated with a subsequent increase in cardiovascular events [25]. Inflammatory processes themselves are risk factors for cardiovascular disease in a variety of populations including those with rheumatoid arthritis [26] and those with bacterial infections [27]. Thus, inflammation can report and play a role in classically initiated vascular injury, while at the same time, inflammation may independently initiate or propagate vascular injury by mechanisms detailed below.

The third potential source of cytokines and the inflammatory response is that associated with release of cytokines by adipocytes [28]. Truncal obesity is associated with increased levels of tumor necrosis factor- $\alpha$ and other downstream cytokines [29], yet obesity is associated with increased survival among dialysis patients [30]. This presents an apparent paradox in linking cytokine activity to cardiovascular risk in this population known as 'reverse epidemiology' [31]. Visceral fat is associated with the metabolic syndrome and alterations in lipoprotein composition that would be expected to result in increased vascular disease. This same association is true in dialysis patients having increased visceral fat [32], and indeed, increased visceral fat mass was associated with increased carotid intimal media thickening, plaque score and stiffness. Others have shown a relationship between carotid atherosclerosis and inflammation, specifically CRP levels and levels of soluble intracellular adhesion molecule and vascular cell adhesion molecule [33]. It is unknown why increased body mass index in the dialysis patient population is not then associated with increased cardiovascular events.

\section{Mechanisms Linking Inflammation Causally to Vascular Injury}

There are multiple mechanisms whereby the inflammatory response can alter blood lipids [34, 35], the vascular endothelium [36], and plasma protein composition in such a way as to favor and promote vascular injury. Additionally, alterations in lipoprotein composition associated with renal failure reduce defense mechanisms that would otherwise mitigate the effects of inflammation on vascular structure (fig. 1).

Atherosclerosis is associated with increased expression of adhesion molecules, such as soluble intracellular adhesion molecule and vascular endothelial growth factor. Vascular endothelial growth factor is released following activation of neutrophils following bacterial infection [37], plays an important role in the maintenance of endothelial integrity [38], but also increases vascular permeability to serum proteins [39]. The biological roles of these proteins provide potential mechanisms whereby inflammation may cause vascular injury by altering the binding of macrophages and other leukocytes to the vascular endothelium. Induction of adhesion molecules facilitates the transmigration by leukocytes [40] and increases mononuclear cell adhesion [41].

Inflammation is associated with cardiovascular disease and stroke in otherwise healthy subjects [42]. While the levels of acute phase proteins remain stable in nondialysis populations [43], inflammation episodically occurs in hemodialysis patients [44].

Inflammation may also downregulate the ATP-binding cassette transporter A1 receptor [45] necessary for the transfer of cholesterol to nascent high-density lipoprotein (HDL) in the initiation of reverse cholesterol transport.

Fibrinogen is a positive acute phase protein which correlates with CRP and is also an independent cardiovascular risk factor [46]. Fibrinogen levels are increased in dialysis patients and correlate with other markers of inflammation [47]. 
Fig. 1. Inflammation initiates increased synthesis of positive acute phase proteins, including CRP, fibrinogen and SAA. Apo AI, the principal protein necessary for HDL synthesis, is decreased resulting in reduced HDL levels. SAA also displaces Apo AI from HDL decreasing its capacity as a reducing agent. Neutrophil activation releases myeloperoxidase which in turn oxidizes LDL. Lecithin cholesterol ester transferase, an enzyme activated by Apo AI that esterifies free cholesterol and is necessary for maturation of HDL, is reduced. Levels of paroxonase and aryl hydrocarbon hydrolase, enzymes utilized by HDL in reducing oxidative injury, are also reduced; thus, HDL fails to block cytokine-mediated expression of the endothelial-derived adhesion molecules soluble intracellular adhesion molecule and E-selectin. Neutrophils are activated releasing myeloperoxidaseoxidizing LDL allowing it to be taken up more easily on the endothelium. LRP $=$ Lipoprotein receptor-related protein; IL-6 = interleukin-6; TNF- $\alpha=$ tumor necrosis factor- $\alpha ; \operatorname{Lp}(\mathrm{a})=$ lipoprotein (a).

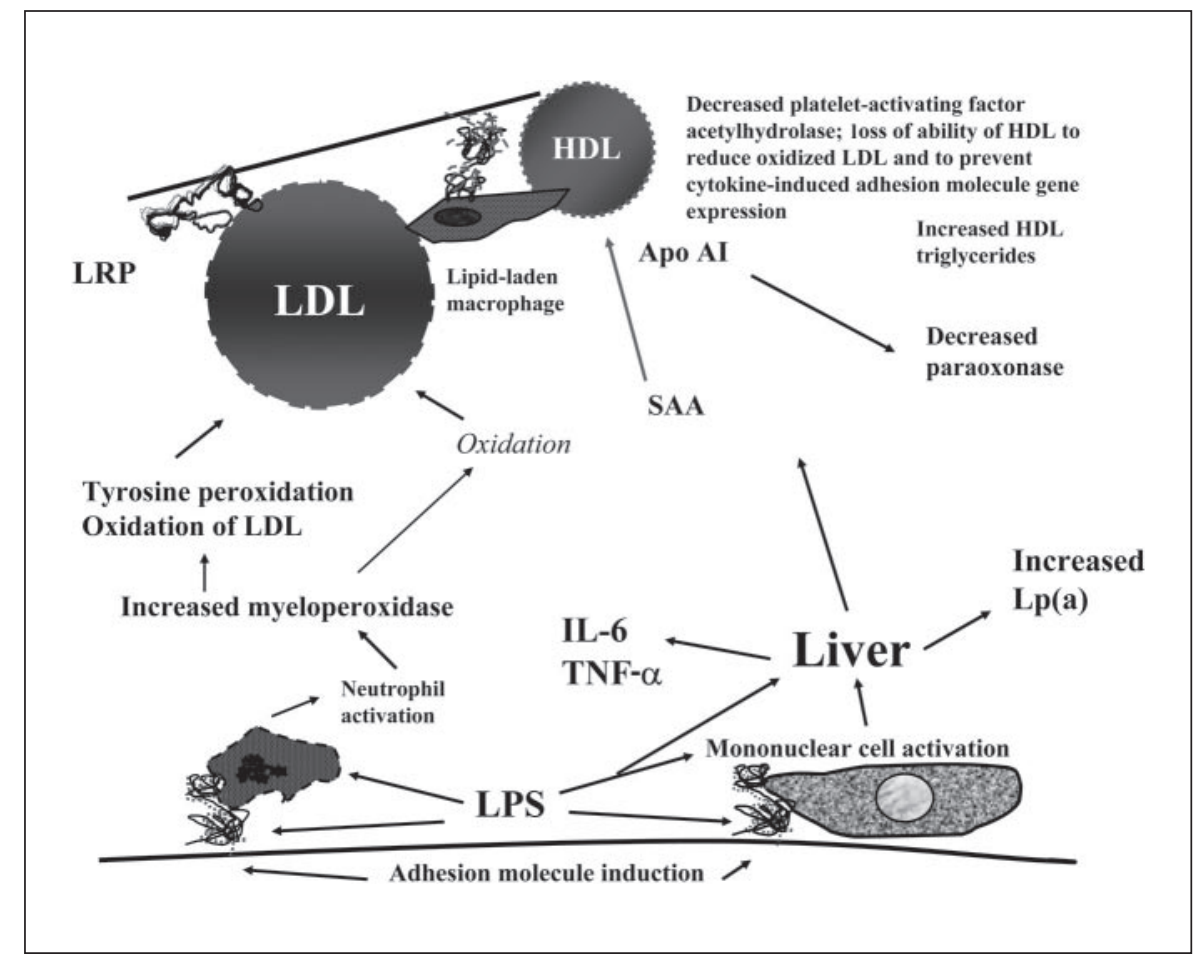

\section{Changes in Lipoprotein Concentration and Composition}

HDL is an important defense mechanism against atherosclerosis, serving both as an anti-oxidant, reducing oxidized low-density lipoprotein (LDL) [48], and decreasing the expression of adhesion molecules induced by cytokines on vascular endothelial cells [49]. HDL levels decrease progressively as renal function fails [50], in part due to a decreased synthesis [51] resulting from downregulation of apolipoprotein (Apo) AI gene expression by the liver [52]. HDL structure is also deranged [53]. In inflamed individuals without renal failure, HDL levels also decrease [34] and the Apo AI that normally composes about half of the proteins in HDL is replaced by serum amyloid A (SAA) [54, 55]. This form of HDL is chemoattractive to macrophages as well as the vascular endothelium and has reduced the capacity to minimize oxidized LDL $[54,55]$. Inflammation alters HDL structure and function removing anti-inflammatory properties by reducing the levels of aryl hydrocarbon hydrolase and paroxynase-1 [55]. Inflammation and the changes in HDL metabolism that occur in renal failure, independently of inflammation, are synergistic in reducing this important defense mechanism against the effects of fur- ther inflammation and produce a positive feedback loop.

Therefore, LDL is more likely to be oxidized during an inflammatory event because of a decreased ability of HDL to protect it and, as a consequence, of increased action of myeloperoxidase, a product of activated neutrophils that chlorinates a tyrosine residue on Apo B100 [34]. Normally, HDL also suppresses the effects of cytokines on their induction of adhesion molecules by endothelial cells [49]. Inflammation alters HDL structure and function to decrease these anti-inflammatory properties. Inflammation would be anticipated to cause a decrease in HDL as well as an increase in triglyceride levels. These same characteristics predict cardiovascular disease in women [56] and are closely associated with markers of inflammation, including SSA levels. This specific acute phase protein directly affects HDL levels [35] and function as well as triglyceride content, suggesting that inflammation may not only play a role in vascular disease, but may also provide a link between progression of renal disease and the lipoprotein abnormalities associated with progression.

Thus, inflammation alters vascular structure and function in ways that allow cholesterol accumulation, decreases the capacity of the endothelium to unload lipids to 
HDL, alters HDL both quantitatively and qualitatively so that it is less able to participate in reverse cholesterol transport and serves as an antioxidant. At the same time, oxidation is increased.

Changes in body composition, decreased muscle mass and decreased levels of albumin and prealbumin normally associated with malnutrition also result from a change in the composition of proteins synthesized by the liver. While the amino acids diverted from muscle and negative acute phase proteins for either energy generation or synthesis of proteins necessary for host defense may serve a protective role under significant inflammatory stress, cachexia has frequently been attributed to malnutrition alone.

\section{References}

1 US Renal Data System: USRDS 2000 annual data report: atlas of end-stage renal diseases in the United States. Bethesda, National Institutes of Health, National Institute of Diabetes and Digestive and Kidney Diseases, 2001.

$>2$ Lowrie EG, Lew NL: Death risk in hemodialysis patients: the predictive value of commonly measured variables and an evaluation of death rate differences between facilities. Am J Kidney Dis 1990;5:458-482.

-3 Yeun JY, Levine RA, Mantadilok V, Kaysen GA: C-reactive protein predicts all-cause and cardiovascular mortality in hemodialysis patients. Am J Kidney Dis 2000;35:469-476. -4 Rao M, Guo D, Perianayagam MC, Tighiouart
H, Jaber BL, Pereira BJ, Balakrishnan VS: Plasma interleukin- 6 predicts cardiovascular mortality in hemodialysis patients. Am J Kidney Dis 2005;45:324-333.

$\checkmark 5$ Rigaud D, Hassid J, Meulemans A, Poupard AT, Boulier A: A paradoxical increase in resting energy expenditure in malnourished patients near death: the king penguin syndrome. Am J Clin Nutr 2000; 72:355-360.

-6 Johansen KL, Kaysen GA, Young BS, Hung AM, da Silva M, Chertow GM: Longitudinal study of nutritional status, body composition, and physical function in hemodialysis patients. Am J Clin Nutr 2003; 77:842-846.

7 Keys A, Brozek J, Henschel A, Mickelson O, Taylor HL: The Biology of Human Starvation. Minneapolis, University of Minnesota Press, 1950.

-8 Haluzik M, Papezova M, Nedvidkova J, Kabrt $\mathrm{J}$ : Serum leptin levels in patients with anorexia nervosa before and after partial refeeding, relationships to serum lipids and biochemical nutritional parameters. Physiol Res 1999;48: 197-202.

-9 Kaysen GA, Chertow GM, Adhikarla R, et al: Inflammation and dietary protein intake exert competing effects on serum albumin and creatinine in hemodialysis patients. Kidney Int 2001;60:333-340.

$>10$ Kaysen GA, Dubin JA, Muller HG, et al: Relationships among inflammation nutrition and physiologic mechanisms establishing albumin levels in hemodialysis patients. Kidney Int 2002;61:2240-2249.
11 Moldawer LL, Copeland EM 3rd: Proinflam-
matory cytokines, nutritional support, and the
cachexia syndrome: interactions and therapeucachexia syndrome: interactions and therapeu

12 Denis C, Guttridge DC, Mayo MW, Madrid LV, Wang CY, Albert S, Baldwin AS Jr: NFkappaB-induced loss of MyoD messenger RNA: possible role in muscle decay and cachexia. Science 2000;289:2363-2366.

13 Lang CH, Frost RA, Nairn AC, MacLean DA, Vary TC: TNF-alpha impairs heart and skeletal muscle protein synthesis by altering translation initiation. Am J Physiol Endocrinol Metab 2002;282:E336-E347.

14 Tisdale MJ: Protein loss in cancer cachexia. Science 2000;289:2293-2294.

15 Li YP, Lecker SH, Chen Y, Waddell ID, Goldberg AL, Reid MB: TNF-alpha increases ubiquitin-conjugating activity in skeletal muscle by up-regulating UbcH2/E220k. FASEB J 2003; 17:1048-1057.

16 Wang ZM, Sun YG, Heymsfield SB: Urinary creatinine-skeletal muscle mass method: a prediction equation based on computerized axial tomography. Biomed Environ Sci 1996;9:185190.

$\checkmark 17$ Kaysen GA, Dubin JA, Muller HG, Rosales L, Levin NW, Mitch WE, HEMO Study Group NIDDK: Inflammation and reduced albumin synthesis associated with stable decline in serum albumin in hemodialysis patients. Kidney Int 2004;65:1408-1415.

18 Melchior JC, Rigaud D, Rozen R, Malon D, Apfelbaum M: Energy expenditure economy induced by decrease in lean body mass in anorexia nervosa. Eur J Clin Nutr 1989;43:793799.

19 Melchior JC, Raguin G, Boulier A, Bouvet E, Rigaud D, Matheron S, Casalino E, Vilde JL, Vachon F, Coulaud JP, et al: Resting energy expenditure in human immunodeficiency virus-infected patients: comparison between patients with and without secondary infections. Am J Clin Nutr 1993;57:614-619.

20 Kirsch R, Frith L, Black E, Hoffenberg R: Regulation of albumin synthesis and catabolism by alteration of dietary protein. Nature 1968;217: 578-579.

-21 Smith G, Weidel SE, Fleck A: Albumin catabolic rate and protein-energy depletion. Nutrition 1994; 10:335-341.
22 Libby P: Inflammation in atherosclerosis. Nature 2002;420:868-874.

23 Turk JR, Carroll JA, Laughlin MH, Thomas TR, Casati J, Bowles DK, Sturek M: C-reactive protein correlates with macrophage accumulation in coronary arteries of hypercholesterolemic pigs. J Appl Physiol 2003;95:13011304.

24 Black S, Kushner I, Samols D: C-reactive protein. J Biol Chem 2004;279:48487-48490.

25 Smeeth L, Thomas SL, Hall AJ, Hubbard R, Farrington P, Vallance P: Risk of myocardial infarction and stroke after acute infection or vaccination. N Engl J Med 2004;351:26112618.

-26 Solomon DH, Karlson EW, Rimm EB, Cannuscio CC, Mandl LA, Manson JE, Stampfer MJ, Curhan GC: Cardiovascular morbidity and mortality in women diagnosed with rheumatoid arthritis. Circulation 2003; 107:13031307.

27 Rupprecht HJ, Blankenberg S, Bickel C, Rippin G, Hafner G, Prellwitz W, Schlumberger W, Meyer J, AutoGene Investigators: Impact of viral and bacterial infectious burden on long-term prognosis in patients with coronary artery disease. Circulation 2001;104:25-31.

28 Lehrke M, Lazar MA: Inflamed about obesity. Nat Med 2004;10:126-127.

29 Piche ME, Lemieux S, Weisnagel SJ, Corneau L, Nadeau A, Bergeron J: Relation of high-sensitivity C-reactive protein, interleukin-6, tumor necrosis factor-alpha, and fibrinogen to abdominal adipose tissue, blood pressure, and cholesterol and triglyceride levels in healthy postmenopausal women. Am J Cardiol 2005; 96:92-97.

30 Johansen KL, Young B, Kaysen GA, Chertow GM: Association of body size with outcomes among patients beginning dialysis. Am J Clin Nutr 2004;80:324-332.

31 Kalantar-Zadeh K, Block G, Humphreys MH, Kopple JD: Reverse epidemiology of cardiovascular risk factors in maintenance dialysis patients. Kidney Int 2003;63:793-808.

32 Yamauchi T, Kuno T, Takada H, Nagura Y, Kanmatsuse K, Takahashi S: The impact of visceral fat on multiple risk factors and carotid atherosclerosis in chronic haemodialysis patients. Nephrol Dial Transplant 2003;18: 1842-1847. 
33 Papagianni A, Kalovoulos M, Kirmizis D, Vainas A, Belechri AM, Alexopoulos E, Memmos D: Carotid atherosclerosis is associated with inflammation and endothelial cell adhesion molecules in chronic haemodialysis patients. Nephrol Dial Transplant 2003;18:113119.

-34 Van Lenten BJ, Hama SY, de Beer FC, et al: Anti-inflammatory HDL becomes pro-inflammatory during the acute phase response. Loss of protective effect of HDL against LDL oxidation in aortic wall cell cocultures. J Clin Invest 1995;96:2758-2767.

35 Artl A, Marsche G, Lestavel S, et al: Role of serum amyloid A during metabolism of acutephase HDL by macrophages. Arterioscler Thromb Vasc Biol 2000;20:763-772.

36 Hwang SJ, Ballantyne CM, Sharrett AR, et al: Circulating adhesion molecules VCAM-1, ICAM-1, and E-selectin in carotid atherosclerosis and incident coronary heart disease cases: the Atherosclerosis Risk In Communities (ARIC) study. Circulation 1997;96:42194225.

>37 Mittermayer F, Pleiner J, Schaller G, et al: Marked increase in vascular endothelial growth factor concentrations during Escherichia coli endotoxin-induced acute inflammation in humans. Eur J Clin Invest 2003;33:758-761.

38 Eremina V, Sood M, Haigh J, et al: Glomerular-specific alterations of VEGF-A expression lead to distinct congenital and acquired renal diseases. J Clin Invest 2003;111:707-716.

39 Carmeliet P: Mechanisms of angiogenesis and arteriogenesis. Nat Med 2000;6:389-395.

40 Yang L, Froio RM, Sciuto TE, Dvorak AM, Alon R, Luscinskas FW: ICAM-1 regulates neutrophil adhesion and transcellular migration of TNF-alpha-activated vascular endothelium under flow. Blood 2005;106:584-592.
41 Kalinina N, Agrotis A, Antropova Y, DiVitto G, Kanellakis P, Kostolias G, Ilyinskaya O, Tararak E, Bobik A: Increased expression of the DNA-binding cytokine HMGB1 in human atherosclerotic lesions: role of activated macrophages and cytokines. Arterioscler Thromb Vasc Biol 2004;24:2320-2325.

42 Ridker PM, Buring JE, Shih J, et al: Prospective study of C-reactive protein and the risk of future cardiovascular events among apparently healthy women. Circulation 1998;98:731733.

43 Ockene IS, Matthews CE, Rifai N, et al: Variability and classification accuracy of serial high-sensitivity C-reactive protein measurements in healthy adults. Clin Chem 2001;47: 444-450.

44 Kaysen GA, Dubin JA, Müller HG, et al: The acute-phase response varies with time and predicts serum albumin levels in hemodialysis patients. Kidney Int 2000;58:346-352.

45 Baranova I, Vishnyakova T, Bocharov A, Chen Z, Remaley AT, Stonik J, Eggerman TL, Patterson AP: Lipopolysaccharide down regulates both scavenger receptor B1 and ATP binding cassette transporter A1 in RAW cells. Infect Immun 2002; 70:2995-3003.

46 Held C, Hjemdahl P, Hakan Wallen N, Bjorkander I, Forslund L, Wiman B, Rehnqvist N: Inflammatory and hemostatic markers in relation to cardiovascular prognosis in patients with stable angina pectoris. Results from the APSIS study. Atherosclerosis 2000; 148:179_ 188.

47 Kaysen GA, Dubin JA, Muller HG, Mitch WE, Rosales L, Levin NW, HEMO Group: Impact of albumin synthesis rate and the acute phase response in the dual regulation of fibrinogen levels in hemodialysis patients. Kidney Int 2003;63:315-322.

48 Mackness MI, Arrol S, Abbott C, et al: Protection of low-density lipoprotein against oxidative modification by high-density lipoprotein associated paraoxonase. Atherosclerosis 1993; 104:129-135.
49 Cockerill GW, Huehns TY, Weerasinghe A, et al: Elevation of plasma high-density lipoprotein concentration reduces interleukin-1-induced expression of E-selectin in an in vivo model of acute inflammation. Circulation 2001; 103:108-112.

-50 Shoji T, Nishizawa Y, Kawagishi T, et al: Atherogenic lipoprotein changes in the absence of hyperlipidemia in patients with chronic renal failure treated by hemodialysis. Atherosclerosis 1997;131:229-236.

-51 Fuh MM, Lee CM, Jeng CY, et al: Effect of chronic renal failure on high-density lipoprotein kinetics. Kidney Int 1990;37:1295-1300.

52 Vaziri ND, Deng G, Liang K: Hepatic HDL receptor, SR-B1 and Apo A-I expression in chronic renal failure. Nephrol Dial Transplant 1999; 14:1462-1466.

53 Atger V, Duval F, Frommherz K, et al: Anomalies in composition of uremic lipoproteins isolated by gradient ultracentrifugation: relative enrichment of HDL in apolipoprotein C-III at the expense of apolipoprotein A-I. Atherosclerosis $1988 ; 74: 75-83$.

54 De Beer FC, Fagan EA, Hughes GRV, Mallya RK, Lanham JG, Pepys MB: Serum amyloid-A protein concentration in inflammatory diseases and its relationship to the incidence of reactive systemic amyloidosis. Lancet 1982;ii:231234.

55 Pruzanski W, Stefanski E, de Beer FC, et al: Comparative analysis of lipid composition of normal and acute-phase high density lipoproteins. J Lipid Res 2000;41:1035-1047.

56 Ridker PM, Hennekens CH, Buring JE, Rifai $\mathrm{N}$ : C-reactive protein and other markers of inflammation in the prediction of cardiovascular disease in women. N Engl J Med 2000;342: 836-843. 